\title{
Prevalence of viral haemorrhagic septicaemia virus in Danish marine fishes and its occurrence in new host species
}

\author{
Helle Frank Skall ${ }^{1, *}$, Niels Jørgen Olesen ${ }^{1}$, Stig Mellergaard ${ }^{2,3}$ \\ ${ }^{1}$ Danish Institute for Food and Veterinary Research, Department of Poultry, Fish and Fur Animals, Hangøvej 2, \\ 8200 Århus N, Denmark \\ ${ }^{2}$ Danish Institute for Fisheries Research, Department for Marine Ecology and Aquaculture, Fish Disease Laboratory, \\ Stigbøjlen 4, 1870 Frederiksberg C, Denmark \\ ${ }^{3}$ Present address: Danish Veterinary and Food Administration, Mørkhøj Bygade 19, 2860 Søborg, Denmark
}

\begin{abstract}
In order to analyse the occurrence of viral haemorrhagic septicaemia virus (VHSV) in the marine waters around Denmark, staff from the Danish Institute for Food and Veterinary Research participated in 5 research cruises during 1998 to 2002 as a follow-up to 4 research cruises performed in 1996 to 1997. In total, 16655 fish were examined virologically as 3569 samples. Forty fish species and 3 invertebrate species were represented. VHSV was isolated from 133 samples representing 8 species: herring Clupea harengus, sprat Sprattus sprattus, dab Limanda limanda, flounder Platichthys flesus, plaice Pleuronectes platessa, cod Gadus morhua, sand eel Ammodytes sp. and sand goby Pomatochistus minutus. Calculations showed that VHSV was more prevalent in the Baltic Sea in an area between Zealand and the island of Bornholm and the waters surrounding Bornholm than in the Kattegat, Skagerrak and along the North Sea coast of Denmark. This is the first report on the isolation of VHSV from dab, flounder and plaice and the first publication on VHSV from sand eel from Europe and sand goby.
\end{abstract}

KEY WORDS: Viral haemorrhagic septicaemia virus · VHSV · Wild fish · Herring · Sprat · Cod · Flatfish $\cdot$ Sand eel $\cdot$ Sand goby

\section{INTRODUCTION}

Since the first isolation from marine fish of viral haemorrhagic septicaemia virus (VHSV) from Atlantic cod Gadus morhua in 1979 (Jensen et al. 1979, Jørgensen \& Olesen 1987), VHSV has been isolated from an increasing number of marine fish species all over the northern hemisphere (Meyers \& Winton 1995, Traxler et al. 1995, 1999, Dixon et al. 1997, Kent et al. 1998, Meyers et al. 1999, Mortensen et al. 1999, Smail 2000, Takano et al. 2000, Cox \& Hedrick 2001, King et al. 2001b, Kocan et al. 2001, Brudeseth \& Evensen 2002, Dopazo et al. 2002, Olivier 2002, Watanabe et al. 2002, Kim et al. 2003).
In order to analyse the occurrence of VHSV in the marine environment surrounding Denmark, staff from the Danish Institute for Food and Veterinary Research (DFVF) participated in 8 research cruises with the Danish research vessel H/S 'Dana' and 1 research cruise with the research vessel 'Havfisken'. The VHSV isolates obtained from material collected during the Dana cruises 1 to 4 have previously been reported (Mortensen et al. 1999). This Note reports on isolation and prevalences of VHSV from marine fish species sampled during the remaining research cruises, including the finding of VHSV in species not previously reported to be VHSV carriers. 


\section{MATERIALS AND METHODS}

Fishing was performed as demersal trawling with a duration of between 15 min and $1 \mathrm{~h}$, in the North Sea, Skagerrak, Kattegat, the Bay of Århus and the Baltic Sea (Fig. 1). The cruises took place in April/May (Dana cruises 5, 6 and 8), in November (Havfisken cruise for $1 \mathrm{~d}$ ) and in February (Dana cruise 7), between 1998 and 2002. The sampling and virological examination were performed as reported previously (Mortensen et al. 1999, Skall et al. 2000). In brief, the samples consisted of tissue from either 1 fish or pooled material of up to 10 fish of the same species. The samples were frozen on board the ship (except for the $1 \mathrm{~d}$ cruise) and kept frozen until further examination. The samples were inoculated on BF-2 cells (Wolf et al. 1966) and positive samples were identified by development of cytopathic effect (CPE), with subsequent confirmation of VHSV by ELISA.

VHSV prevalence $(p)$ and the $95 \%$ confidence interval $\left(\mathrm{CI}_{95 \%}\right)$ were calculated for herring, sprat, cod, dab, flounder and sand goby, based on randomly selected fish sampled in pools of 5 or 10 fish, comprising at least 30 fish in all. The following formulae were used: Estimated proportion of positive fish: $p=1-(1-P)^{1 / C}$. Proportion of positive pools: $P=S / R$, where $S$ is the number of positive pools, $R$ is the total number of pools and $C$ is the number of fish in each pool (Kline et al. 1989);

$$
\begin{aligned}
& P_{\mathrm{L}}=\frac{\left(2 S+1.96^{2}-1\right)-1.96 \sqrt{1.96^{2}-\left(2+\frac{1}{R}\right)+\frac{4 S(R-S+1)}{R}}}{2\left(R+1.96^{2}\right)} \\
& P_{\mathrm{U}}=\frac{\left(2 S+1.96^{2}+1\right)-1.96 \sqrt{1.96^{2}+\left(2-\frac{1}{R}\right)+\frac{4 S(R-S-1)}{R}}}{2\left(R+1.96^{2}\right)}
\end{aligned}
$$

where $P_{\mathrm{L}}$ and $P_{\mathrm{U}}$ are the lower and upper limit for $P$, respectively. Substitute these limits for $p$ in the equation to obtain limits for $\mathrm{p}\left(p_{\mathrm{L}}, p_{\mathrm{U}}\right.$ ) (Hauck 1991). If $S \simeq 0$, substitute ${ }_{\mathrm{E}} P_{\mathrm{U}}=1-0.05^{1 / R}$ for $p$ in the equation to obtain limits for $p\left(p_{\mathrm{U}}\right)$, where ${ }_{\mathrm{E}} \mathrm{P}_{\mathrm{U}}$ is the exact limit for $P$.

\section{RESULTS AND DISCUSSION}

In total, 16655 fish were examined virologically in 3569 samples, representing 40 fish species and 3 invertebrate species. VHSV was isolated from 132 samples consisting of 850 fish and representing 8 species (Table 1): Atlantic herring Clupea harengus, sprat Sprattus sprattus, dab Limanda limanda, flounder Platichthys flesus, plaice Pleuronectes platessa, Atlantic cod Gadus morhua, sand eel Ammodytes sp. and sand goby Pomatochistus minutus. Information on each virus isolate is given in Table 2. VHSV has been reported in Atlantic herring (Dixon et al. 1997, Mortensen et al. 1999, King et al. 2001b), sprat (Mortensen et al. 1999) and Atlantic cod (Jensen et al. 1979, Jørgensen \& Olesen 1987, Mortensen et al. 1999, Smail 2000, King et al. 2001b). This is the first report describing the isolation of VHSV in dab, flounder and plaice, all belonging to the flatfish family Pleuronectidae (some isolates have been used in infection trials and results were published in Skall et al. 2004). Dab (536 fish), flounder (25 fish) and plaice (217 fish) were sampled in previous cruises without isolation of VHSV, all mainly in pools with 10 fish. Most of these dab originated from the North Sea (346 fish), and the remaining fish from the Kattegat (86), the Lofoten region (42) and western Scotland (59). Plaice were mainly sampled in the Lofoten (105) and western Scotland (75) 
Table 1. VHSV-positive fish species examined during cruises with H/S 'Dana' and 'Havfisken' during 1998 to 2002 . The following are shown for the different waters and species: Samples = number of VHSV positive samples/total number of samples; Fish $=$ number of fish in the VHSVpositive samples/total number of fish in all samples. Note that not all the fish included in a VHSV-positive sample may necessarily have been VHSV positive

\begin{tabular}{|c|c|c|c|c|c|c|c|c|c|c|c|}
\hline \multirow{3}{*}{$\begin{array}{l}\text { Common } \\
\text { name }\end{array}$} & \multirow{3}{*}{$\begin{array}{r}\text { Fish species } \\
\text { Latin } \\
\text { name }\end{array}$} & \multirow{2}{*}{\multicolumn{2}{|c|}{ North Sea }} & \multirow{2}{*}{\multicolumn{2}{|c|}{ Skagerrak }} & \multicolumn{4}{|l|}{ Water } & \multicolumn{2}{|c|}{$\longrightarrow$ Total $\longrightarrow$} \\
\hline & & & & & & Katt & egat & Baltic & Sea & & \\
\hline & & Samples & Fish & Samples & Fish & Samples & Fish & Samples & Fish & Samples & Fish \\
\hline Herring & Clupea harengus & $0 / 35$ & $0 / 175$ & $2 / 33$ & $10 / 225$ & $6 / 115$ & $60 / 1095$ & 68/1513 & $310 / 4204$ & $76 / 1696$ & $380 / 5699$ \\
\hline Sprat & Sprattus sprattus & $0 / 20$ & $0 / 100$ & $0 / 21$ & $0 / 175$ & $0 / 48$ & $0 / 472$ & $36 / 344$ & $335 / 2291$ & $36 / 433$ & $335 / 3038$ \\
\hline Dab & Limanda limanda & $0 / 61$ & $0 / 301$ & $0 / 18$ & $0 / 85$ & $6 / 115$ & $33 / 814$ & $1 / 8$ & $10 / 72$ & $7 / 202$ & $43 / 1,272$ \\
\hline Flounder & Platichthys flesus & $0 / 2$ & $0 / 7$ & 0 & 0 & $0 / 6$ & $0 / 35$ & $6 / 71$ & $36 / 389$ & $6 / 79$ & $36 / 431$ \\
\hline Plaice & Pleuronectes platessa & $0 / 50$ & $0 / 250$ & $1 / 20$ & $10 / 104$ & $1 / 19$ & $5 / 121$ & $0 / 10$ & $0 / 56$ & $2 / 99$ & $15 / 531$ \\
\hline Sand goby & Pomatochistus minutus & 0 & 0 & 0 & 0 & 0 & 0 & $3 / 21$ & $30 / 210$ & $3 / 21$ & $30 / 210$ \\
\hline Sand eel & Ammodytes sp & $0 / 6$ & $0 / 28$ & $0 / 17$ & $0 / 85$ & $0 / 6$ & $0 / 60$ & $1 / 10$ & $6 / 79$ & $1 / 39$ & $6 / 252$ \\
\hline Cod & Gadus morhua & $0 / 9$ & $0 / 45$ & $0 / 33$ & $0 / 178$ & $0 / 55$ & $0 / 384$ & $1 / 315$ & $5 / 1432$ & $1 / 412$ & $5 / 2039$ \\
\hline \multicolumn{2}{|c|}{ Total } & $0 / 183$ & $0 / 906$ & $3 / 142$ & $20 / 852$ & $13 / 364$ & $98 / 2981$ & $116 / 2292$ & $732 / 8733$ & $132 / 2981$ & $850 / 13472$ \\
\hline
\end{tabular}

Table 2. Name of VHSV isolates from the scientific cruises with the research ship H/S 'Dana', cruises 5 to 8 . All isolates starting with 5 are from 1998, with 6 from 1999, 7 from 2001 and 8 from 2002. An 'e' in the name indicates that the isolation was made from a single fish, whereas a ' $\mathrm{p}$ ' indicates isolation from a pooled sample. The species from which the isolates originate, the ICES squares and the corresponding catchment areas are stated

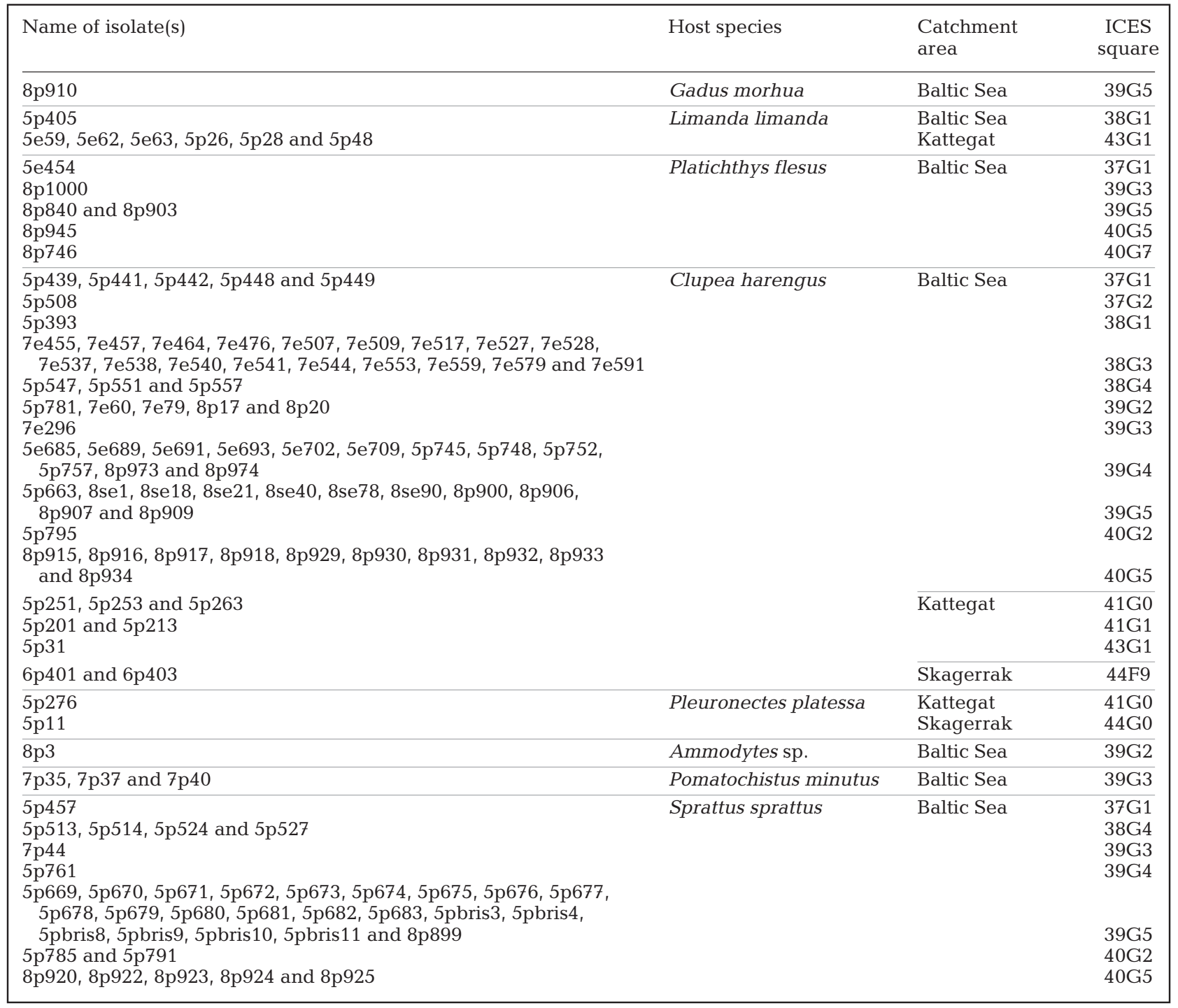




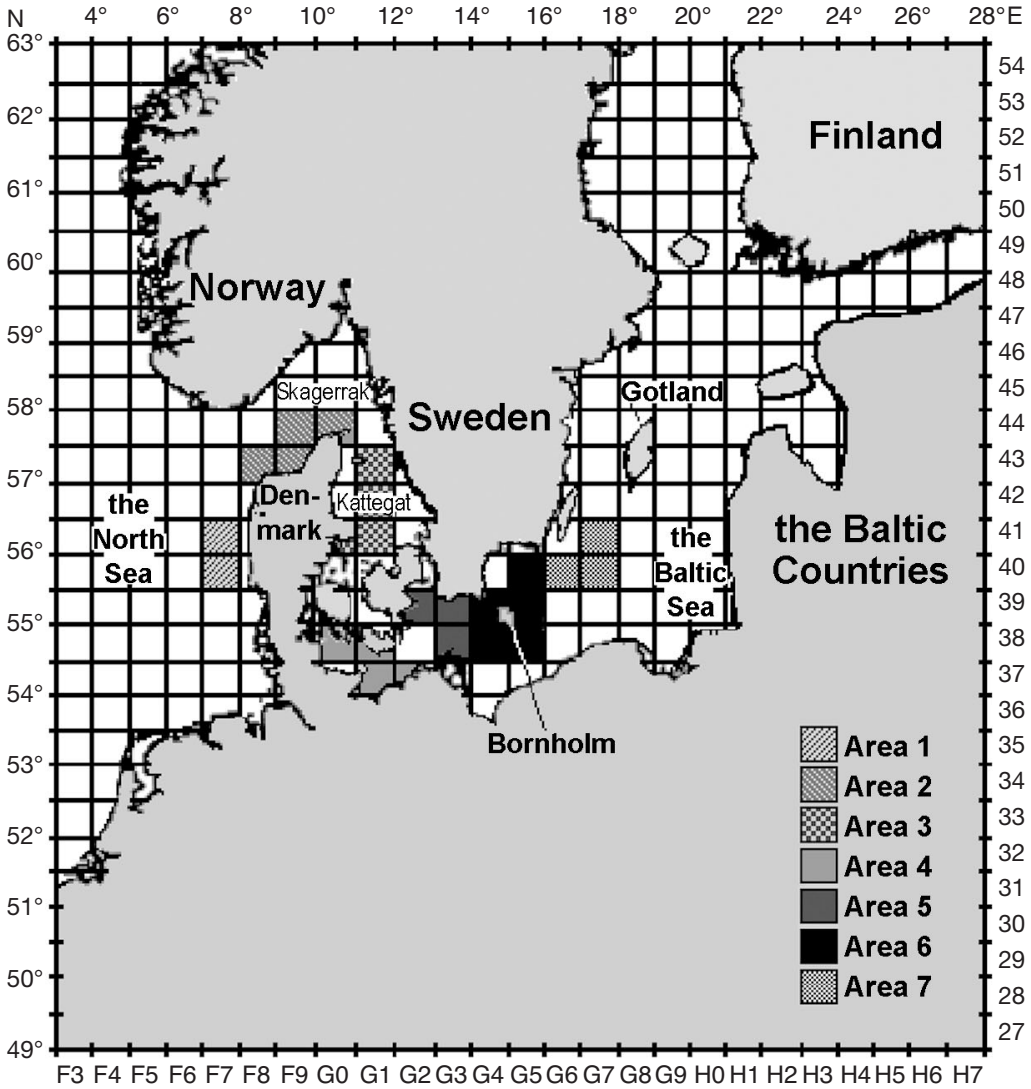

Fig. 2. Areas for which VHSV prevalences were calculated for herring, sprat, cod, dab, flounder and sand goby. Prevalences are shown in Table 3. Numbers and letters on the lower $x$ - and right $y$-axis indicate ICES squares

VHSV has been isolated from 2 other Ammodytes species: A. hexapterus from the North American Pacific area (Kocan et al. 2001) and A. personatus from Japan (Watanabe et al. 2002). The isolation of VHSV from sand goby is the first report of VHSV isolation from a fish within the family Gobiidae. Sand goby (260 fish, pools with 10 fish) has previously only been sampled on the south coast of Norway (Brudeseth \& Evensen 2002).

Most of the VHSV-positive samples consisted of fish with no visible signs of disease, except parasitic infections. A pool of 10 dab with epidermal papillomas was VHSV positive, and 3 single dab with lymphocystis were VHSV positive. In one haul, all the herring had haemorrhages in the eyes, which were attributed to net damages. From this haul, 2 pools of 5 herring were VHSV positive and 8 pools were VHSV negative.

The calculated prevalences (Fig. 2, Table 3) indicate that VHSV prevalence in the waters around Denmark is highest in Areas 5 and 6, both of which are in the Baltic Sea and extend from Zealand to and around the island of Bornholm. For the different cruises the calculated prevalence for the area around Bornholm (Area 6) varied between 0 and $16.7 \%$ for herring and 0.0 and $7.8 \%$ for sprat. From

(Mortensen et al. 1999, King et al. 2001b, Brudeseth \& Evensen 2002). Most of the fish were thus sampled in areas from which VHSV has either not been isolated from these species or has not been isolated at all. VHSV has previously been reported in Pleuronectidae, in Greenland halibut Reinhardtius hippoglossoides from the North American Atlantic area (Dopazo et al. 2002) and English sole Parohrys vetulus from the North American Pacific area (Hershberger \& Kocan unpubl. in Hershberger et al. 1999). With respect to flatfish, VHSV has furthermore been isolated in Japan from farmed and wild Japanese flounder Paralichthys olivaceus, belonging to the family Paralichthyidae (Takano et al. 2000, Isshiki et al. 2001) and in Europe from farmed turbot Scophthalmus maximus, belonging to the family Scophthalmidae (Schlotfeldt et al. 1991, Ross et al. 1994). In Europe, VHSV has not previously been isolated from sand eel. The exact species sampled in this study is unknown, but is either $A$. marinus and/or A. tobianus. Sand eel (91 fish, mainly pools with 10 fish) has previously been sampled in the Skagerrak and the North Sea, without isolation of VHSV (Mortensen et al. 1999, Brudeseth \& Evensen 2002).
1 haul in Area 6, 30 and 100 herring were sampled singly on Dana cruises 5 and 8, respectively, giving a prevalence of $20 \%\left(\mathrm{CI}_{95 \%}: 8.4\right.$ to $\left.39.1 \%\right)$ and $6 \%$ $\left(\mathrm{CI}_{95 \%}: 2.5\right.$ to $\left.13.1 \%\right)$, respectively. As the species of the sand eel is unknown, and the samples may be a mixture of Ammodytes marinus and A. tobianus, prevalences have not been calculated.

The calculated prevalences are only indicative, as the calculations are based on the assumptions that the fish are caught and sampled randomly, which is not the case, as the trawl selects the size of the fish depending of the mesh size in the codend. It is also assumed that the sensitivity of the test is equal, regardless of the number of fish in the sample, which may not be true either. Furthermore, the sampling effort was more intense in the Baltic Sea compared to the other waters, which may partly account for the 'missing' VHSV isolations in the other areas.

The large numbers of VHSV isolations support the conclusions reported in Mortensen et al. (1999) that VHSV is widespread in the waters around Denmark, and can be found in the Baltic Sea comparatively frequently among herring and sprat. It furthermore con- 
Table 3. Calculations of VHSV prevalence (Prev., \%) for selected fish species. Calculations are based on randomly selected fish sampled in pools of 5 or 10 fish. The different areas are shown in Fig. 2 by colour coding. $\mathrm{CI}_{95 \%} 95 \%$ : confidence interval. nd: lack of samples fulfilling the requirements of 5 or 10 randomly selected fish per pool and/or at least $30 \mathrm{fish}$ in all. -: no fish of the respective species were caught in the area. ${ }^{*}$ : VHSVpositive fish of the respective species were caught in the area

\begin{tabular}{|c|c|c|c|c|c|c|c|c|c|c|c|c|c|c|}
\hline \multirow{2}{*}{$\begin{array}{l}\text { Dana } \\
\text { cruise }\end{array}$} & \multicolumn{2}{|c|}{ Area 1} & \multicolumn{2}{|c|}{ Area 2} & \multicolumn{2}{|c|}{ Area 3} & \multicolumn{2}{|c|}{ Area 4} & \multicolumn{2}{|c|}{ Area 5} & \multicolumn{2}{|c|}{ Area 6} & \multicolumn{2}{|c|}{ Area 7} \\
\hline & Prev. & $\mathrm{CI}_{95 \%}$ & Prev. & $\mathrm{CI}_{95 \%}$ & Prev. & $\mathrm{CI}_{95 \%}$ & Prev. & $\mathrm{CI}_{95 \%}$ & Prev. & $\mathrm{CI}_{95 \%}$ & Prev. & $\mathrm{CI}_{95 \%}$ & Prev. & $\mathrm{CI}_{95 \%}$ \\
\hline \multicolumn{15}{|l|}{ Sprat } \\
\hline 5 & - & & nd & & $0^{\mathrm{b}}$ & $0.0-0.7^{b}$ & $0.6^{\mathrm{b}}$ & $0.0-3.4^{\mathrm{b}}$ & $0^{\mathrm{b}}$ & $0.0-9.5^{\mathrm{b}}$ & $7.8^{\mathrm{b}}$ & $4.7-11.8^{b}$ & nd & \\
\hline 6 & $0^{\mathrm{a}}$ & $0.0-3.0^{\mathrm{a}}$ & $0^{a, b}$ & $\begin{array}{l}0.0-8.2^{\mathrm{a}} \\
0.0-2.7^{\mathrm{b}}\end{array}$ & $0^{\mathrm{b}}$ & $0.0-5.8^{\mathrm{b}}$ & - & & - & & - & & - & \\
\hline 7 & - & & - & & - & & - & & $0.9^{\mathrm{b}}$ & $0.0-5.4^{\mathrm{b}}$ & $0^{\mathrm{b}}$ & $0.0-4.9^{\mathrm{b}}$ & - & \\
\hline 8 & - & & - & & - & & - & & nd & & $\begin{array}{l}5.6^{\mathrm{a}} \\
0.9^{\mathrm{b}}\end{array}$ & $\begin{array}{c}2.0-12.7^{\mathrm{a}} \\
0.0-5.4^{\mathrm{b}}\end{array}$ & $0^{\mathrm{a}}$ & $0.0-1.3^{a}$ \\
\hline \multicolumn{15}{|c|}{ Herring } \\
\hline 5 & - & & nd & & $0.7^{\mathrm{b}}$ & $0.2-1.9^{\mathrm{b}}$ & $1.4^{\mathrm{b}}$ & $0.6-3.1^{\mathrm{b}}$ & nd $^{*}$ & & $1.9^{\mathrm{b}}$ & $0.8-4.0^{\mathrm{b}}$ & $0^{\mathrm{b}}$ & $0.0-1.0^{\mathrm{b}}$ \\
\hline 6 & $0^{\mathrm{a}}$ & $0.0-1.7^{a}$ & $\begin{array}{l}2.1^{\mathrm{a}} \\
0^{\mathrm{b}}\end{array}$ & $\begin{array}{l}0.4-7.7^{\mathrm{a}} \\
0.0-3.0^{\mathrm{b}}\end{array}$ & nd & & - & & - & & - & & - & \\
\hline 7 & - & & - & & - & & - & & $0^{\mathrm{b}}$ & $0.0-4.9^{\mathrm{b}}$ & $0^{\mathrm{b}}$ & $0.0-9.5^{\mathrm{b}}$ & - & \\
\hline 8 & - & & - & & - & & - & & $\begin{array}{l}4.4^{\mathrm{a}} \\
0^{\mathrm{b}}\end{array}$ & $\begin{array}{c}0.7-15.1^{\mathrm{a}} \\
0.0-9.5^{\mathrm{b}}\end{array}$ & $\begin{array}{l}16.7^{\mathrm{a}} \\
4.4^{\mathrm{b}}\end{array}$ & $\begin{array}{l}8.7-27.5^{\mathrm{a}} \\
1.3-10.9^{\mathrm{b}}\end{array}$ & $0^{\mathrm{a}}$ & $0.0-1.1^{a}$ \\
\hline \multicolumn{15}{|l|}{ Cod } \\
\hline 5 & - & & nd & & $0^{\mathrm{b}}$ & $0.0-7.2^{\mathrm{b}}$ & $0^{\mathrm{b}}$ & $0.0-2.3^{b}$ & nd & & $0^{\mathrm{b}}$ & $0.0-4.9^{\mathrm{b}}$ & $0^{\mathrm{b}}$ & $0.0-2.7^{b}$ \\
\hline 6 & $0^{\mathrm{a}}$ & $0.0-6.4^{\mathrm{a}}$ & $0^{\mathrm{a}}$ & $0.0-3.7^{a}$ & $0^{\mathrm{b}}$ & $0.0-3.7^{b}$ & - & & - & & - & & - & \\
\hline 7 & - & & - & & - & & - & & $0^{\mathrm{b}}$ & $0.0-4.9^{\mathrm{b}}$ & - & & - & \\
\hline 8 & - & & - & & - & & - & & $0^{\mathrm{a}, \mathrm{b}}$ & $0.0-9.5^{\mathrm{a}, \mathrm{b}}$ & $\begin{array}{c}1.7^{\mathrm{a}} \\
0^{\mathrm{b}}\end{array}$ & $\begin{array}{l}0.1-9.8^{\mathrm{a}} \\
0.0-9.5^{\mathrm{b}}\end{array}$ & $0^{\mathrm{a}}$ & $0.0-2.3^{\mathrm{a}}$ \\
\hline \multicolumn{15}{|l|}{ Dab } \\
\hline 5 & - & & - & & $1.5^{\mathrm{b}}$ & $0.4-4.4^{\mathrm{b}}$ & $0^{\mathrm{b} *}$ & $0.0-9.5^{\mathrm{b}}$ & - & & - & & - & \\
\hline 6 & $0^{\mathrm{a}}$ & $0.0-1.1^{\mathrm{a}}$ & $0^{\mathrm{a}}$ & $0.0-4.2^{\mathrm{a}}$ & $0^{a, b}$ & $\begin{array}{l}0.0-5.8^{\mathrm{a}} \\
0.0-2.0^{\mathrm{b}}\end{array}$ & - & & - & & - & & - & \\
\hline 7 & - & & - & & - & & - & & nd & & - & & - & \\
\hline 8 & - & & - & & - & & - & & - & & - & & - & \\
\hline \multicolumn{15}{|c|}{ Flounder } \\
\hline 5 & - & & - & & nd & & $\mathrm{nd}^{*}$ & & - & & nd & & nd & \\
\hline 6 & nd & & - & & nd & & - & & - & & - & & - & \\
\hline 7 & - & & - & & - & & - & & $0^{\mathrm{b}}$ & $0.0-9.5^{\mathrm{b}}$ & - & & - & \\
\hline 8 & - & & - & & - & & - & & $4.0^{\mathrm{b}}$ & $0.2-18.8^{\mathrm{b}}$ & $\begin{array}{l}7.8^{\mathrm{a}} \\
1.8^{\mathrm{b}}\end{array}$ & $\begin{array}{c}1.2-24.8^{\mathrm{a}} \\
0.1-9.6^{\mathrm{b}}\end{array}$ & $2.6^{\mathrm{a}}$ & $0.1-14.1^{\mathrm{a}}$ \\
\hline \multicolumn{15}{|c|}{ Sand goby } \\
\hline 5 & - & & - & & - & & - & & - & & - & & - & \\
\hline 6 & - & & - & & - & & - & & - & & - & & - & \\
\hline 7 & - & & - & & - & & - & & - & & $1.5^{\mathrm{b}}$ & $0.4-4.6^{\mathrm{b}}$ & - & \\
\hline 8 & - & & - & & - & & - & & - & & - & & - & \\
\hline
\end{tabular}

firms that the number of fish species that may carry VHSV is high. The results obtained during Dana cruise 6 support results from earlier Dana cruises that the VHS virus is not very prevalent in the North Sea off the Danish west coast, where no VHSV has so far been isolated. Furthermore, VHSV was not isolated from any of the fish sampled north of Gotland $\left(>58.5^{\circ} \mathrm{N}\right.$, Dana cruise 8, Fig. 1), despite the fact that 579 herring and 605 sprat were sampled. In addition, 883 three-spined sticklebacks Gasterosteus aculeatus were sampled in the same area, without any VHSV isolations, a species from which VHSV has been isolated in North America (Kent et al. 1998, Anonymous 2001). This is the first publication on sampling from the area north of Gotland.

Investigations conducted during Dana cruise 7 showed that it was possible to isolate VHSV in the winter months from wild marine fish in the Baltic Sea. 
The results also showed that VHSV prevalence among herring varied considerably ( 0 to $12 \%$ ) between the different catches, within a small area, suggesting that different levels of infection occurred in different schools of herring.

Together with the results reported from previously reported cruises (Mortensen et al. 1999), the number of fish and species examined by DFVF in the waters surrounding Denmark summarizes to 49 fish species comprising 23703 fish in 4440 samples and 3 invertebrate species, an isopod Saduria entomon (256 from the Baltic Sea in 47 samples), krill Euphausia sp. (30 from the Kattegat in 3 samples) and squid Loligo sp. (10 from the Kattegat in 1 sample). Thirteen of these species consisted of $<10$ specimens each, and 27 fish species of $<50$ specimens each. VHSV was isolated from 163 samples in total, representing 13 fish species, namely herring (87), sprat Sprattus sprattus (44), cod (7), dab (7), flounder (6), sand goby (3), plaice (2), whiting Merlangius merlangus (2), blue whiting Micromesistius poutassou (1), fourbeard rockling Enchelyopus cimbrius (1), lesser argentine Argentina sphyraena (1), Norway pout Trisopterus esmarkii (1) and sand eel (1). VHSV was not isolated from haddock Melanogrammus aeglefinus (148 fish from the Skagerrak) and saithe Pollachius sp. (85 fish from the Skagerrak), both belonging to the family Gadidae as cod, during the Danish cruises. VHSV has been isolated from haddock previously (Smail 2000). Brudeseth \& Evensen (2002) did not succeed in isolating VHSV from 200 haddock caught in the Skagerrak. Likewise, VHSV was not isolated from lemon sole Microstomus kitt (20 fish from the North Sea, 54 fish from the Skagerrak) or from long rough dab Hippoglossoides platessoides (80 fish from the Kattegat, 48 from the Skagerrak, 49 from the North Sea), both belonging to the subfamily Pleuronectinae which includes dab, flounder and plaice.

Of species caught in quantities $\geq 50$ during all the Danish cruises, blue whiting, horse mackerel Trachurus trachurus (except for 2 fish), Norway pout, saithe Pollachius sp. and pearlsides Maurolicus muelleri were unique to the cruises reported in Mortensen et al. (1999). Lemon sole (except for 1 fish), plaice (except for 9 fish), sand goby, sand eel (except for 30 fish), smelt Osmerus eperlanus and three-spined sticklebacks (except for 8 fish) were unique to the cruises reported herein.

The isolates from Dana cruise 5 have been investigated in infection trials in rainbow trout Oncorhynchus mykiss, and found to be non-pathogenic to this species by immersion, similar to the isolates from Dana cruises 1 to 4 , and in contrast to classical rainbow trout isolates (Skall et al. 2004). These isolates, together with a few isolates from Dana cruises 6 and 7, were sequenced, and found to belong to genotypes Ib and II, both consisting of isolates from wild marine fish (Einer-Jensen et al. 2004, Snow et al. 2004).

As reported earlier (Mortensen et al. 1999, King et al. 2001b), most of the VHSV isolations came from fish without clinical signs attributable to VHS. Whether this is because VHSV from the marine environment in Europe does not cause disease in wild marine fish or whether VHSV-positive fish are carrier fish that have survived VHS is not known. It has been shown experimentally that the European VHSV isolates from wild marine fish can be pathogenic to turbot Scophthalmus maximus by immersion (King et al. 2001a), whereas a VHSV isolate from wild Atlantic cod did not induce mortality in Atlantic cod exposed by immersion (Snow et al. 2000). VHSV has not been isolated from natural mass mortalities among wild marine fishes in Europe, as in North America (Meyers et al. 1999, Traxler et al. 1999). Infection studies using Pacific herring Clupea pallasi showed that this species is highly susceptible to the North American VHSV strain, with mortalities up to $100 \%$ (Kocan et al. 1997). No infection trials using Atlantic herring and European VHSV isolates have been performed to date. However, such experiments would be essential in obtaining knowledge on the epidemiological implications of marine VHSV in the stock regulation of species such as herring, sprat and Norway pout.

Acknowledgements. The Danish Institute for Fisheries and Marine Research (DIFRES), and in particular Dr. I. Dalsgaard, are acknowledged for help in planning and carrying out Dana cruises 5 and 6, and for giving us the opportunity to use the research vessels. The crew on board the research vessels are also thanked for their assistance and for making the cruise a pleasant experience. M. Busse, I. Hornum, M. Scherfig and O. Madvig from DIFRES are acknowledged for their practical assistance on board the ship on the various cruises. The technicians N. Nicolajsen, S. Madsen, A. E. Nielsen, H. T. T. Tran, M. Eliassen, I. Høgh, M. Jarnum and J. Mølgaard, all DFVF, are acknowledged for their assistance on board the ship on the various cruises, as well as in the laboratory. The land-based technicians at DFVF are acknowledged for their help in processing the samples in the laboratory. Dr. E. Lorenzen and Dr. E. Ariel, both DFVF, are acknowledged for their help on various cruises. Dr. S. Helgason, University of Iceland, and Dr. J. M. Fregeneda Grandes, University of Leon, Spain are acknowledged for their help on board the ship during their research stay at DFVF. Dr. A. Alfjorden, National Veterinary Institute, Sweden, is acknowledged for his help on board the ship during the latest cruise. Biologists from the county of Århus are acknowledged for allowing DFVF personnel to attend the cruise with 'Havfisken'. Part of this work was performed during the ECproject 'Rhabdoviruses in wild marine fish in European coastal waters: Characterisation and significance for aquaculture (FAIR CT 96-1594)'. The research school SCOFDA (Sustainable Control of Fish Diseases in Aquaculture) is also acknowledged for financial support. 


\section{LITERATURE CITED}

Anonymous (2001) Report of the working group on pathology and diseases of marine organisms, Santiago de Compostela, 13-17 Mar 2001. ICES CM2001/F:02

Brudeseth BE, Evensen $\varnothing$ (2002) Occurrence of viral haemorrhagic septicaemia virus (VHSV) in wild marine fish species in the coastal regions of Norway. Dis Aquat Org 52:21-28

Cox B, Hedrick R (2001) VHS virus in pacific sardines and mackerel. Am Fish Soc Newsl (Fish Health Sect) 29:6

Dixon PF, Feist S, Kehoe E, Parry L, Stone DM, Way K (1997) Isolation of viral haemorrhagic septicaemia virus from Atlantic herring Clupea harengus from the English Channel. Dis Aquat Org 30:81-89

Dopazo CP, Bandín I, López-Vazquez C, Lamas J, Noya M, Barja JL (2002) Isolation of viral hemorrhagic septicemia virus from Greenland halibut Reinhardtius hippoglossoides caught at the Flemish Cap. Dis Aquat Org 50: 171-179

Einer-Jensen K, Ahrens P, Forsberg R, Lorenzen N (2004) Evolution of the fish rhabdovirus viral haemorrhagic septicaemia virus. J Gen Virol 85:1167-1179

Hauck WW (1991) Confidence intervals for seroprevalence determined from pooled sera. Ann Epidemiol 1:277-281

Hershberger PK, Kocan RM, Elder NE, Meyers TR, Winton JR (1999) Epizootiology of viral hemorrhagic septicemia virus in Pacific herring from the spawn-on-kelp fishery in Prince William Sound, Alaska, USA. Dis Aquat Org 37:23-31

Isshiki T, Nishizawa T, Kobayashi T, Nagano T, Miyazaki T (2001) An outbreak of VHSV (viral hemorrhagic septicemia virus) infection in farmed Japanese flounder Paralichthys olivaceus in Japan. Dis Aquat Org 47:87-99

Jensen NJ, Bloch B, Larsen JL (1979) The ulcus-syndrome in cod (Gadus morhua). III. A preliminary virological report. Nord Vet Med 31:436-442

Jørgensen PEV, Olesen NJ (1987) Cod ulcus syndrome rhabdovirus is indistinguishable from the Egtved (VHS) virus. Bull Eur Assoc Fish Pathol 7:73-74

Kent ML, Traxler GS, Kieser D, Richard J and 5 others (1998) Survey of salmonid pathogens in ocean-caught fishes in British Columbia, Canada. J Aquat Anim Health 10: 211-219

Kim SU, Lee JI, Hong MJ, Park HS, Park SI (2003) Genetic relationship of the VHSV (viral hemorrhagic septicemia virus) isolated from cultured olive flounder, Paralichthys olivaceus in Korea. J Fish Pathol 16:1-12

King JA, Snow M, Skall HF, Raynard RS (2001a) Experimental susceptibility of Atlantic salmon Salmo salar and turbot Scophthalmus maximus to European freshwater and marine isolates of viral haemorrhagic septicaemia virus. Dis Aquat Org 47:25-31

King JA, Snow M, Smail DA, Raynard RS (2001b) Distribution of viral haemorrhagic septicaemia virus in wild fish species of the North Sea, north east Atlantic Ocean and Irish Sea. Dis Aquat Org 47:81-86

Kline RL, Brothers TA, Brookmeyer R, Zeger S, Quicc TC (1989). Evaluation of human immunodeficiency virus (HIV) seroprevalence in population surveys using pooled sera. J Clin Microbiol 27:1449-1452

Kocan R, Bradley M, Elder N, Meyers TR, Batts WN, Winton JR (1997) North American strain of viral hemorrhagic septicemia virus is highly pathogenic for laboratory-reared pacific herring. J Aquat Anim Health 9:279-290

Kocan RM, Hershberger PK, Elder NE, Winton JR (2001) Epidemiology of viral hemorrhagic septicemia among juve- nile pacific herring and Pacific sand lances in Puget Sound, Washington. J Aquat Anim Health 13:77-85

Meyers TR, Winton JR (1995) Viral hemorrhagic septicemia virus in North America. Annu Rev Fish Dis 5:3-24

Meyers TR, Short S, Lipson K (1999) Isolation of the North American strain of viral hemorrhagic septicemia virus (VHSV) associated with epizootic mortality in two new host species of Alaskan marine fish. Dis Aquat Org 38:81-86

Mortensen HF, Heuer OE, Lorenzen N, Otte L, Olesen NJ (1999) Isolation of viral haemorrhagic septicaemia virus (VHSV) from wild marine fish species in the Baltic Sea, Kattegat, Skagerrak and the North Sea. Virus Res 63: 95-106

Olivier G (2002) Disease interactions between wild and cultured fish-perspectives from the American Northeast (Atlantic Provinces). Bull Eur Assoc Fish Pathol 22: 103-109

Ross K, McCarthy U, Huntly PJ, Wood BP, Stuart D, Rough EI, Smail DA, Bruno DW (1994) An outbreak of viral haemorrhagic septicaemia (VHS) in turbot (Scophthalmus maximus) in Scotland. Bull Eur Assoc Fish Pathol 14:213-214

Schlotfeldt HJ, Ahne W, Jørgensen PEV, Glende W (1991) Occurrence of viral haemorrhagic septicaemia in turbot (Scophthalmus maximus) - a natural outbreak. Bull Eur Assoc Fish Pathol 11:105-107

Skall HF, Mellergaard S, Olesen NJ (2000) Isolation of Birnavirus serogroup B in wild and aquacultured fish species. Bull Eur Assoc Fish Pathol 20:229-236

Skall HF, Slierendrecht WJ, King JA, Olesen NJ (2004) Experimental infection of rainbow trout Oncorhynchus mykiss with viral haemorrhagic septicaemia virus isolates from European marine and farmed fishes. Dis Aquat Org 58: 99-110

Smail DA (2000) Isolation and identification of viral haemorrhagic septicaemia (VHS) viruses from cod Gadus morhus with the ulcus syndrome and from haddock Melanogrammus aeglefinus having skin haemorrhages in the North Sea. Dis Aquat Org 41:231-235

Snow M, Cunningham CO, Bricknell IR (2000) Susceptibility of juvenile Atlantic cod Gadus morhua to viral haemorrhagic septicaemia virus isolated from wild-caught Atlantic cod. Dis Aquat Org 41:225-229

Snow M, Bain N, Black J, Taupin V, Cunningham CO, King JA, Skall HF, Raynard RS (2004) Genetic population structure of marine viral haemorrhagic septicaemia virus (VHSV). Dis Aquat Org 61:11-21

Takano R, Nishizawa T, Arimoto M, Muroga K (2000) Isolation of viral haemorrhagic septicaemia virus (VHSV) from wild Japanese flounder, Paralichthys olivaceus. Bull Eur Assoc Fish Pathol 20:186-192

Traxler G, Kieser D, Evelyn TPT (1995) Isolation of North American strain of VHS virus from farmed Atlantic salmon. In: Margolis L (ed) Aquaculture update no. 72. Aquaculture Divison, Pacific Biological Station, Nanaimo, BC, p 1-2

Traxler GS, Kieser D, Richard J (1999) Mass mortality of pilchard and herring associated with viral hemorrhagic septicemia virus in British Columbia, Canada. Am Fish Soc Newsl (Fish Health Sect) 27:3-4

Watanabe L, Pakingking RJ, Iida $H$, Nishizawa T, Iida $Y$, Arimoto M, Muroga K (2002) Isolation of aquabirnavirus and viral hemorrhagic septicemia virus (VHSV) from wild marine fishes. Fish Pathol 37:189-191

Wolf K, Gravell M, Malmsberger RG (1966) Lymphocystis virus: isolation and propagation in centrarchid fish cell lines. Science 151:1004-1005

Submitted: April 7, 2004; Accepted: May 3, 2005

Proofs received from author(s): August 12, 2005 